\title{
The compensatory response of pigs previously fed a diet with an increased fibre content. 2. Chemical body components and composition of daily gain*
}

\author{
G. Skiba ${ }^{1}$, St. Raj, D. Weremko and H. Fandrejewski \\ The Kielanowski Institute of Animal Physiology and Nutrition, \\ Polish Academy of Sciences \\ 05-110 Jabłonna, Poland
}

(Received 15 February 2006; revised version 22 March 2006; accepted 5 July 2006)

\begin{abstract}
The composition of the daily gain of pigs previously fed a high-fibre diet (HF) was investigated in 60 pigs growing from 25 to $105 \mathrm{~kg}$ body weight (BW) using a comparative slaughter technique. From $25 \mathrm{~kg}$ body weight (BW), the pigs were fed the HF diet up to 50 (group HF50) or 80 (group HF80) $\mathrm{kg} \mathrm{BW}$, followed by feeding with the conventional low-fibre diet (LF). The pigs of groups LF105 and HF105 were continuously fed diet LF or HF, respectively. When the HF diet was fed, the daily empty body gain of the HF50 and HF80 pigs was lower $(\mathrm{P}<0.05)$ compared with the LF105 animals. Similarly, the daily protein $(\mathrm{P}<0.01)$ and fat deposition (difference not significant) of the HF50 pigs was lower than in the LF group. The pigs of the HF80 group tended $(\mathrm{P}=0.09)$ to deposit less protein daily, and their daily fat deposition was lower $(\mathrm{P}<0.01)$ than in the LF105 animals. During the first stage of realimentation ( 50 to $80 \mathrm{~kg} \mathrm{BW})$, pigs from group HF50 grew faster and deposited more $(\mathrm{P}<0.01)$ protein daily (169 g) compared with the LF105 (132 g) and HF105 animals (139 g). Nonetheless, the pigs of groups HF50 and LF105 deposited similar amounts of fat (291 and $296 \mathrm{~g}$, respectively), whereas those of group HF105, considerably less $(208 \mathrm{~g}$; $\mathrm{P}<0.05)$. During subsequent realimentation (80-105 kg BW) the empty body gain of pigs did not differ significantly among groups (on average 916 $\mathrm{g})$. Despite the absence of differences in growth rates, daily protein accretion in the pigs from groups HF80 and HF105 tended $(\mathrm{P}<0.07)$ to be higher (by $14 \mathrm{~g}$ ) compared with those from group LF105. During this period, pigs from groups HF50 and HF80 deposited more fat daily (on average by $110 \mathrm{~g}$; $\mathrm{P}<0.01$ ) than those of groups LF105 and HF 105 . These results prove that the compensatory response is closely associated with higher protein deposition and with better protein utilization for growth.
\end{abstract}

KEY WORDS: pig, compensatory growth, composition of daily gain, body composition, dietary fibre

\footnotetext{
* Supported by The European Commission (the V Framework Programme) within Project "Sustainability in the production of pork with improved nutritional and eating quality using strategic feeding in outdoor production". Contract No. QLK5-CT-2000-00162

${ }^{1}$ Corresponding author: e-mail: g.skiba@ifzz.pan.pl
} 


\section{INTRODUCTION}

Roughage feeds commonly fed to animals kept outdoors worsen their performance compared with conventionally reared animals. Therefore, in this type of production, much attention is paid to finding a way that would improve the growth performance of pigs. It seems that an alternative could be via the compensatory growth phenomenon, which improves the performance of previously restricted animals (de Greef, 1992; Bikker, 1994; Skiba et al., 2001). In earlier studies on the compensatory response, pigs were restricted in terms of protein (de Greef, 1992) or feed/energy intake (Bikker, 1994). The type of restriction applied, as well as its duration, differently influenced the subsequent compensatory response, especially with regards to the chemical composition of daily gain (Skiba et al., 2001). Both kinds of previous restriction resulted in periodically enhanced daily protein deposition during the following growth period. Fat deposition was, however, significantly greater in pigs previously restricted with feed/energy intake.

A recent literature search did not return studies on the influence of feeding pigs with a high-fibre diet on their subsequent compensatory response. Therefore, this study was conducted to test the influence a high fibre diet on the composition the daily gain of pigs during consumption of that diet and after returning to conventional feeding. It was hypothesized that pigs previously consuming a diet with increased fibre will show a compensatory response after returning to a conventional diet, and that their body and gain composition will be changed.

\section{MATERIAL AND METHODS}

Sixty crossbreed gilts ( $\overbrace{}^{\wedge}$ Duroc $\times \uparrow$ Large White) were kept individually from 25 to $105 \mathrm{~kg}$ body weight (BW) in $2.6 \mathrm{~m}^{2}$ pens equipped with an automatic feeder and nipple drinker. The pigs were continuously fed a conventional diet (LF, group LF105) ad libitum, or a diet with an increased fibre content (HF, group HF105). The remaining animals were fed the HF diet up to 50 (group HF50) or 80 (group HF80) kg BW, followed by the LF diet. Detailed information on feeding strategy and diet composition is given in the first part of this study (Skiba et al., 2006). It was assumed that the pigs of group LF 105 were simulating conventional feeding and the pigs of group HF105, outdoor feeding (due to the consumption of a large amount of fibre). The pigs in groups HF50 and HF80 were simulating animals that were fed according to an outdoor feeding strategy for a certain period, after which a compensatory growth phenomenon was incorporated into their growth pathway. 
The comparative slaughter technique as described by Kotarbińska (1971) was used to calculate the gain of the chemical body components. Before slaughter, the pigs were transported individually to the Institute's experimental slaughterhouse, located about $20 \mathrm{~m}$ from the pig house, stunned electrically, exsanguinated and scalded. The number of animals slaughtered at a particular BW was limited as much as possible due to the costs and labour-intensity of the experiment. Thus, at $25 \mathrm{~kg}$ BW (beginning of the experiment) six of the "zero" pigs were slaughtered. Next, at $50 \mathrm{~kg} \mathrm{BW}$, six pigs from group LF105 and two pigs each from groups HF50, HF80 and HF105 were randomly selected and slaughtered. At $80 \mathrm{~kg} \mathrm{BW}$, six pigs from group LF105 and three pigs each from groups HF80 and HF105 were slaughtered. Finally, at $105 \mathrm{~kg} \mathrm{BW}$, six pigs from each of the four groups (LF105, HF105, HF80, HF50) were slaughtered. The design of the experiment and number of animals are presented in Table 1, the design of the slaughter of pigs in Table 2.

Table 1. Design of the experiment

\begin{tabular}{|c|c|c|c|}
\hline \multirow{2}{*}{ Group } & \multicolumn{3}{|c|}{ Feed applied during particular growth period } \\
\hline & $25-50 \mathrm{~kg} \mathrm{BW}$ & $50-80 \mathrm{~kg} \mathrm{BW}$ & $80-105 \mathrm{~kg} \mathrm{BW}$ \\
\hline LF105 & $\mathrm{LF}(\mathrm{n}=18)$ & $\mathrm{LF}(\mathrm{n}=12)$ & $\mathrm{LF}(\mathrm{n}=6)$ \\
\hline HF50 & $\mathrm{HF}(\mathrm{n}=14)$ & $\mathrm{LF}(\mathrm{n}=12)$ & $\mathrm{LF}(\mathrm{n}=6)$ \\
\hline HF80 & $\mathrm{HF}(\mathrm{n}=11)$ & $\mathrm{HF}(\mathrm{n}=9)$ & $\operatorname{LF}(n=6)$ \\
\hline HF105 & $\mathrm{HF}(\mathrm{n}=11)$ & $\mathrm{HF}(\mathrm{n}=9)$ & $\mathrm{HF}(n=6)$ \\
\hline
\end{tabular}

LF-low fibre diet, HF- high fibre diet, LF105- group of pigs fed the LF diet throughout the study, HF50- group of pigs fed the diet HF up to $50 \mathrm{~kg} \mathrm{BW}$ following the diet LF, HF80- group of pigs fed the diet HF up to $80 \mathrm{~kg} \mathrm{BW}$ following the diet LF, HF105- group of pigs fed the diet HF throughout the experiment

Table 2. Design of the slaughter of pigs

\begin{tabular}{lcccc}
\hline \multirow{2}{*}{ Group } & \multicolumn{5}{c}{ No of pig slaughtered at particular body weight, $\mathrm{kg}$} \\
\cline { 2 - 5 } & 25 & 50 & 80 & 105 \\
\hline LF105 & 6 & 6 & 6 \\
HF105 & 2 & 3 & 6 \\
HF80 & 2 & 3 & 6 \\
HF50 & total 6 & 2 & 6 & 6 \\
\hline
\end{tabular}

LF105- group of pigs fed the LF diet throughout the study, HF50- group of pigs fed the diet HF up to $50 \mathrm{~kg} \mathrm{BW}$ following the diet LF, HF80- group of pigs fed the diet HF up to $80 \mathrm{~kg} \mathrm{BW}$ following the diet LF, HF105- group of pigs fed the diet HF throughout the experiment

The contents of chemical components (water, protein, fat (ether extract) and ash) were determined according to AOAC methods (1994). Protein and energy utilization were subsequently calculated using the following formula:

protein utilization $=($ daily protein deposited in the body/daily intake of digestible protein $) \times 100$ 
energy utilization $=($ total daily energy deposited in the body as fat and protein/daily intake of energy) $\times 100$

To calculate the amount of energy deposited in the body, $23.86 \mathrm{~kJ}$ for protein and $39.76 \mathrm{~kJ}$ for fat were used.

The adiposity relative to body weight was determined using the allometric equation $Y=a \times X^{b}$ developed by Huxley (1932). In this case $Y$ was the fat:protein ratio related to $X$, representing the empty body weight (EBW), $a$ was the intercept, and $b$ was the slope of the regression line (the so-called growth coefficient).

Statistical analysis was performed by ANOVA analysis of variance and regression analysis using Statgraphics Centurion version 15 software.

\section{RESULTS}

\section{Restriction period}

The values given in the text and tables as HF50 are averages for pigs from groups HF50, HF80 and HF105, those given as HF80 are averages for HF80 and HF105 pigs, as the pigs of these groups were treated similarly during particular stages of the restriction period.

The content of chemical components in the empty body did not differ significantly between the LF105 and HF50 pigs (Table 3). The content of water, protein and ash in the HF80 pigs was, however, increased $(\mathrm{P}<0.05)$, and fat content, decreased $(\mathrm{P}<0.05)$ compared with the LF105 pigs by 5.5, 5.1, 12.8 and $15.6 \%$, respectively.

Table 3. Content of chemical components, $\mathrm{g} / \mathrm{kg}$ : water $(\mathrm{W})$, protein $(\mathrm{P})$, fat $(\mathrm{F})$, ash in the body at the end of the restriction period

\begin{tabular}{lllcccc}
\hline Restriction & Group & $\mathrm{n}$ & $\mathrm{W}$ & $\mathrm{P}$ & $\mathrm{F}$ & Ash \\
\hline $25-50 \mathrm{~kg} \mathrm{BW}$ & LF105 & 6 & 600 & 169 & 146 & 24.8 \\
& HF50 & 6 & 660 & 166 & 139 & 23.9 \\
& SEM & & 7.99 & 2.68 & 5.24 & 0.58 \\
& $\mathrm{P}$ & & $\mathrm{NS}$ & $\mathrm{NS}$ & $\mathrm{NS}$ & $\mathrm{NS}$ \\
& & & & & & \\
& LF105 & 6 & 595 & 158 & 212 & 23.6 \\
& HF80 & 6 & 628 & 166 & 179 & 26.5 \\
& SEM & & 8.90 & 5.97 & 23.8 & 2.07 \\
& P & & $*$ & $*$ & $*$ & $*$ \\
\hline
\end{tabular}

${ }^{1}$ average for treatment HF50 and HF80 and HF105; ${ }^{2}$ average for treatment HF80 and HF105;

$* \mathrm{P}<0.05$; NS - non significant 
Daily empty body gain (EBG) of pigs from group HF50 was lower $(\mathrm{P}<0.001)$ compared with the pigs of group LF105 (691 vs $802 \mathrm{~g}$ ) (Table 4). Daily protein deposition of HF50 pigs was $24 \mathrm{~g}$ /day lower $(\mathrm{P}<0.01)$, but no significant differences in protein utilization were found. Daily deposition of fat in pigs of the HF50 group decreased by $28 \mathrm{~g}$ (difference not significant), and their daily ash deposition was $3.8 \mathrm{~g}$ lower $(\mathrm{P}<0.01)$. Utilization of energy did not differ significantly between LF105 and HF50 animals.

Table 4. Daily gain (g) of the empty body (EBG), water (W), protein (P), fat (F), ash and utilization of protein and energy during the restriction period

\begin{tabular}{|c|c|c|c|c|c|c|c|c|c|}
\hline \multirow{2}{*}{ Restriction } & \multirow{2}{*}{ Group } & \multirow[b]{2}{*}{$\mathrm{n}$} & \multirow{2}{*}{ EBG } & \multirow{2}{*}{ W } & \multirow{2}{*}{$\mathrm{P}$} & \multirow{2}{*}{$F$} & \multirow{2}{*}{ Ash } & \multicolumn{2}{|c|}{ Utilization } \\
\hline & & & & & & & & protein & energy \\
\hline \multirow[t]{4}{*}{$25-50 \mathrm{~kg} \mathrm{BW}$} & LF105 & 6 & 802 & 490 & 140 & 151 & 20.6 & 49.8 & 37.5 \\
\hline & $\mathrm{HF} 50^{1}$ & 6 & 691 & 436 & 116 & 122 & 16.8 & 46.5 & 33.8 \\
\hline & SEM & & 13.4 & 16.55 & 5.55 & 10.40 & 0.7 & 2.65 & 1.77 \\
\hline & $\mathrm{P}$ & & $* * *$ & NS & $* *$ & NS & $* *$ & NS & NS \\
\hline \multirow[t]{4}{*}{$25-80 \mathrm{~kg} \mathrm{BW}$} & LF105 & 6 & 876 & 489 & 136 & 230 & 20.7 & 40.0 & 42.6 \\
\hline & $\mathrm{HF} 80^{2}$ & 6 & 767 & 453 & 127 & 166 & 21.2 & 43.7 & 36.2 \\
\hline & SEM & & 14.7 & 12.9 & 3.42 & 11.42 & 0.8 & 1.66 & 1.51 \\
\hline & $\mathrm{P}$ & & $* *$ & NS & NS & $* *$ & NS & NS & $*$ \\
\hline
\end{tabular}

${ }^{1}$ average for treatment HF50 and HF80 and HF105; ${ }^{2}$ average for treatment HF80 and HF105; *** $\mathrm{P}<0.001 ; * * \mathrm{P}<0.01 ; * \mathrm{P}<0.05$; NS - non significant

The empty body gain (EBG) of pigs of the HF80 group was $109 \mathrm{~g}$ lower than the LF105 pigs. Moreover, the pigs of the HF80 group tended $(\mathrm{P}<0.09)$ to have deposited less protein daily, and their daily fat deposition decreased by 64 $g(\mathrm{P}<0.01)$ compared with the pigs of group LF105. The efficiency of protein utilization did not differ, but utilization of energy was $6.4 \%$ better $(\mathrm{P}<0.05)$ in the HF80 pigs compared with the LF105 animals.

\section{Realimentation period}

The body protein content in the middle of the realimentation period $(80 \mathrm{~kg}$ $\mathrm{BW})$ of the HF50 and HF105 pigs was higher $(\mathrm{P}<0.05)$ compared with the pigs of group LF105 (166 and $166 \mathrm{vs} 158 \mathrm{~g} / \mathrm{kg}$; Table 5). The fat content in the body, however, took the following order $(\mathrm{P}<0.07): 180 \mathrm{~g} / \mathrm{kg}$ (group HF105), $196 \mathrm{~g} / \mathrm{kg}$ (group HF50) and $212 \mathrm{~g} / \mathrm{kg}$ (group LF105). The ash content in the body of HF105 and HF50 pigs was higher than in the LF105 animals (26.5 and $25.7 \mathrm{vs} 23.6 \mathrm{~g} / \mathrm{kg}$; $\mathrm{P}<0.05$ ).

The empty body gain (EBG) of pigs in group HF50 during growth from 50 to $80 \mathrm{~kg} \mathrm{BW}$, was highest $(\mathrm{P}<0.05)$ compared with the LF105 and HF105 pigs $(980$ 
vs 918 and $872 \mathrm{~g}$ /day), (Table 6). Group HF50 pigs deposited more protein daily than the LF105 and HF105 animals (169 vs 132 and 139 g, respectively; $\mathrm{P}<0.01$ ). The pigs from groups HF50 and LF105, however, deposited a similar amount of fat (291 vs $296 \mathrm{~g}$ ), whereas those from group HF105 deposited considerably less of this body component $(208 \mathrm{~g}$; $\mathrm{P}<0.05)$. Daily water accretion did not differ among groups. The animals in group HF50 did show, however, the highest $(\mathrm{P}<0.01)$ daily accretion of ash $(28.8 \mathrm{~g})$ compared with pigs from groups HF105 and LF105 (25.7 and $20.3 \mathrm{~g}$, respectively). Moreover, the efficiency of protein utilization differed $(\mathrm{P}<0.05)$ between groups $(41.6,40.3$ and $34.1 \%$, respectively for the HF105, HF50 and LF105 pigs). Energy utilization by pigs from groups LF105 and HF50 did not differ significantly (43.9 and 43.6\%, respectively), however it was insignificantly higher than in HF105 (37.8\%).

The final protein and ash content in the body (at $105 \mathrm{~kg} \mathrm{BW}$ ) did not differ significantly among treatments (Table 5 ). The water content, however, differed $(\mathrm{P}<0.01)$ between the HF105 and LF105, HF50 and HF80 pigs (603 vs 573, 554 and $584 \mathrm{~g} / \mathrm{kg}$, respectively). HF105 pigs had the lowest fat content in the body $(207 \mathrm{~g} / \mathrm{kg})$, whereas those of groups HF50, HF80 and LF105 were fatter $(267,234$ and $249 \mathrm{~g} / \mathrm{kg}$, respectively; $\mathrm{P}<0.01$ ).

Table 5. Content of chemical components, $\mathrm{g} / \mathrm{kg}$ : water $(\mathrm{W})$, protein $(\mathrm{P})$, fat $(\mathrm{F})$, ash in the empty body at the middle $(80 \mathrm{~kg})$ and at the end of the realimentation period $(105 \mathrm{~kg})$

\begin{tabular}{lllcccc}
\hline Realimentation & Group & $\mathrm{n}$ & $\mathrm{W}$ & $\mathrm{P}$ & $\mathrm{F}$ & Ash \\
\hline $50-80 \mathrm{~kg}$ & LF105 & 6 & 606 & 158 & 212 & 23.6 \\
& HF50 & 6 & 612 & 166 & 196 & 25.7 \\
& HF105 & 6 & 628 & 166 & 180 & 26.5 \\
& SEM & & 10.21 & 2.20 & 7.93 & 0.63 \\
& P & & NS & $*$ & NS & $*$ \\
$80-105 \mathrm{~kg}$ & LF105 & 6 & 573 & 152 & 249 & 26.3 \\
& HF50 & 6 & 554 & 153 & 267 & 26.2 \\
& HF80 & 6 & 584 & 156 & 234 & 25.9 \\
& HF105 & 6 & 603 & 162 & 207 & 27.7 \\
& SEM & & 7.96 & 3.20 & 9.14 & 0.49 \\
& P & & $* *$ & NS & $* *$ & NS \\
\hline
\end{tabular}

${ }^{1}$ average for group HF80 and HF $105 ; * * \mathrm{P}<0.01 ; * \mathrm{P}<0.05$; NS - non significant

The average daily gain of EBG of pigs growing from 80 to $105 \mathrm{~kg} \mathrm{BW}$ did not differ significantly among groups (Table 6). In spite of this, daily protein accretion in the group HF80 and HF105 pigs tended to be higher $(\mathrm{P}<0.07)$ compared with those of groups LF105 and HF50 (148, 147 vs 133, 133 g, respectively). The pigs in groups HF50 and HF80 deposited more fat daily (441 and $364 \mathrm{~g}$, respectively; $\mathrm{P}<0.01$ ) than those in groups LF105 and HF105 (332 and $254 \mathrm{~g}$, respectively). 
Daily water deposition differed $(\mathrm{P}<0.05)$ between treatments and took the following order: $458 \mathrm{~g}$ (group HF105), $453 \mathrm{~g}$ (group LF105), 374 (group HF80), and $302 \mathrm{~g}$ (group HF50).

The pigs of group HF105 and HF80 utilized digestible protein more efficiently $(\mathrm{P}<0.05)$ as compared with the HF50 and LF105 animals (34.3 and 31.4 vs 26.6 and $28.2 \%$, respectively). Metabolizable energy utilization by pigs from groups HF50 and HF80, however, was the best (48.4 and 44.0\%, respectively) and higher $(\mathrm{P}<0.01)$ than in the pigs in groups LF105 and HF105 (40.2 and 34.9\%, respectively).

Table 6. Daily gain (g) of the empty body (EBG), water (W), protein (P), fat (F), ash and utilisation of digestible protein and metabolizable energy during the realimentation period

\begin{tabular}{|c|c|c|c|c|c|c|c|c|c|}
\hline \multirow{2}{*}{ Realimentation } & \multirow{2}{*}{ Group } & \multirow{2}{*}{$\mathrm{n}$} & \multirow{2}{*}{ EBG } & \multirow{2}{*}{$\mathrm{W}$} & \multirow{2}{*}{$\mathrm{P}$} & \multirow{2}{*}{$\mathrm{F}$} & \multirow{2}{*}{ Ash } & \multicolumn{2}{|c|}{ Utilization } \\
\hline & & & & & & & & protein & energy \\
\hline \multirow[t]{5}{*}{$50-80 \mathrm{~kg} \mathrm{BW}$} & LF105 & 6 & 918 & 470 & 132 & 296 & 20.3 & 34.1 & 43.9 \\
\hline & HF50 & 6 & 980 & 491 & 169 & 291 & 28.8 & 40.3 & 43.6 \\
\hline & $\mathrm{HF} 105^{1}$ & 6 & 872 & 499 & 139 & 208 & 25.7 & 41.6 & 37.8 \\
\hline & SEM & & 18.1 & 23.5 & 6.45 & 27.2 & 1.6 & 2.70 & 2.84 \\
\hline & $\mathrm{P}$ & & $*$ & NS & $* *$ & $*$ & $* *$ & $*$ & NS \\
\hline \multirow[t]{6}{*}{ 80-105 kg BW } & LF105 & 6 & 952 & 453 & 133 & 332 & 34.3 & 28.2 & 40.2 \\
\hline & HF50 & 6 & 907 & 302 & 133 & 441 & 30.8 & 26.6 & 48.4 \\
\hline & HF80 & 6 & 915 & 374 & 148 & 364 & 28.6 & 31.4 & 44.0 \\
\hline & HF105 & 6 & 890 & 458 & 147 & 254 & 31.2 & 34.3 & 34.9 \\
\hline & SEM & & 61.5 & 42.1 & 5.84 & 34.55 & 2.43 & 2.11 & 2.67 \\
\hline & $\mathrm{P}$ & & NS & $*$ & NS & $* *$ & NS & $*$ & $*$ \\
\hline
\end{tabular}

${ }^{1}$ average for group HF80 and HF105; ${ }^{*} \mathrm{P}<0.01 ;{ }^{*} \mathrm{P}<0.05$; NS - non significant

\section{Overall growth period}

The EBG of the HF50 and LF105 animals was higher $(\mathrm{P}<0.01)$ compared with the pigs in groups HF80 and HF105 (895 and 892 vs 815 and 831 g, respectively; Table 7). Daily deposition of protein, water and ash did not differ significantly among treatments. Even so, the pigs in groups HF50 and LF105 deposited more fat daily (287 and $264 \mathrm{~g}$, respectively; $\mathrm{P}<0.01$ ) as compared with groups HF80 and HF105 (226 and $194 \mathrm{~g}$, respectively).

The pigs in group HF105 utilized digesible protein more efficiently $(\mathrm{P}<0.01)$ as compared with the HF50, HF80 and LF105 animals (40.1 vs 34.0, 36.6 and $34.8 \%$, respectively). Group LF105, HF50 and HF80 pigs utilized metabolizable energy similarly and better $(\mathrm{P}<0.01)$ than the pigs in group HF105 $(41.8,42.6$ and 39.1 vs $36.0 \%$, respectively). 
Table 7. Daily gain (g) of the empty body $(\mathrm{EBG})$, water $(\mathrm{W})$, protein $(\mathrm{P})$, fat $(\mathrm{F})$, ash and utilization of digestible protein and metabolizable energy during the overall growth period (25-105 $\mathrm{kg} \mathrm{BW})$

\begin{tabular}{lcccccccc}
\hline \multirow{2}{*}{ Group } & \multirow{2}{*}{$\mathrm{N}$} & EBG & W & P & F & Ash & \multicolumn{2}{c}{ Utilization } \\
\cline { 7 - 9 } & & & & & & & protein & energy \\
\hline HF105 & 6 & 892 & 471 & 133 & 264 & 24.4 & 34.8 & 41.8 \\
HF80 & 6 & 895 & 449 & 134 & 287 & 24.9 & 34.0 & 42.6 \\
HF105 & 6 & 815 & 440 & 126 & 226 & 22.6 & 36.6 & 39.1 \\
SEM & 6 & 831 & 478 & 135 & 194 & 24.2 & 40.1 & 36.0 \\
P value & & \multirow{2}{*}{18.0} & 19.76 & 4.79 & 12.36 & 0.87 & 1.61 & 0.94 \\
\hline
\end{tabular}

** $\mathrm{P}<0.01 ; * \mathrm{P}<0.05 ; \mathrm{NS}$ - non significant

Body adiposity expressed as the body fat:protein ratio (F:P) (Table 8) differed significantly among groups, as coefficient $\mathrm{b}$ of the allometric equation ranged from 0.48 (group HF105) to 0.80 (group HF50). When the fat:protein ratio was calculated for a constant EBW (100 kg), it was found that the highest value was in pigs from group HF50 (1.59), followed by LF105 and HF80 pigs (1.51 and 1.46), with the lowest in the group of HF105 animals (1.28).

Table 8 . Accretion rate of body fatness expressed by the ratio of fat:protein in the body during the experiment

\begin{tabular}{lccccccc}
\hline Group & \multicolumn{1}{c}{$\mathrm{Y}$} & $\mathrm{a}$ & $\mathrm{X}$ & $\mathrm{b}$ & $\mathrm{r}$ & $\begin{array}{c}\mathrm{Y} \text {, when } \\
\mathrm{X}=100 \mathrm{~kg}\end{array}$ \\
\hline LF105 & & $0.05 \pm 0.03$ & & $0.74 \pm 0.14, \quad \mathrm{P}<0.0001$ & 0.93 & 1.51 \\
HF50 & Ratio of & $0.04 \pm 0.03$ & EBW & $0.80 \pm 0.16, \quad \mathrm{P}<0.0001$ & 0.85 & 1.59 \\
HF80 & F:P & $0.08 \pm 0.05$ & & $0.63 \pm 0.14, \quad \mathrm{P}<0.0001$ & 0.83 & 1.46 \\
HF105 & $0.14 \pm 0.63$ & & $0.48 \pm 0.11, \quad \mathrm{P}<0.0001$ & 0.80 & 1.28 \\
\hline
\end{tabular}

$\mathrm{a}$ - an intercept; $\mathrm{b}$ - a slope of the regression line (growth coefficient); F:P - ratio of fat:protein in the body; EBW - empty body weight

\section{DISCUSSION}

Feeding animals the high-fibre diet for a short time (up to $50 \mathrm{~kg}$ ) did not change their chemical body composition compared with pigs fed a standard diet. When, however, such feeding was prolonged until a heavier body weight was reached ( 80 $\mathrm{kg} \mathrm{BW})$, the protein content in the body increased and the fat content decreased. Comparing this response with the results of a previous study on compensatory growth, it was found that our pigs responded to restriction similarly to pigs with restricted feed/energy intake (Bikker, 1994), as animals restricted only in terns of protein intake always increased their body fat content at the end of the restriction (de Greef, 1992). 
It is known that a change in the composition of daily body weight gain accompanies compensatory growth, and that the greatest changes concern protein and fat deposition. It is also well known that these changes depend on the type of previous restriction (de Greef, 1992; Bikker, 1994; Skiba et al., 2002). In our experiment, both groups of compensating animals (from 50 and from $80 \mathrm{~kg} \mathrm{BW}$ ) deposited more protein than the pigs in the LF105 group. This response was the most evident for a short period after removal of the growth suppressor (diet HF). During the later period of realimentation, enhanced protein deposition gradually diminished. This was a typical response, also observed in previous work on compensatory growth, however, in that study the observation was based mainly on changes in daily gain during the realimentation period (Skiba et al., 2001).

When trying to explain the compensatory protein deposition, we conclude that the reasons put forward to date do not give a clear answer as to which process plays a crucial role. It is thought a complex of several mechanisms/events occurring during this time is responsible (Lawrence and Fowler, 2002; Skiba, 2005). The results of the experiment presented here, however, indicate that one of the reasons for the higher compensatory protein deposition could be improved utilization of protein, considered as the percentage of feed digestible protein converted into protein deposited in the body, since in both groups of compensating pigs, protein utilization was superior to that in pigs from the groups continuously fed a standard diet (however, it was slightly worse in comparison with the pigs fed the high-fibre diet throughout the experiment).

The unexpectedly best protein utilization by the HF 105 pigs growing from 80 to $105 \mathrm{~kg}$ BW was undoubtedly a result of these pigs (especially their gastrointestinal tract) adapting to the high-fibre diet. This adaptation allowed them to deposit even the same amount of protein during this time as to the pigs compensating from 80 kg BW (group HF80). Moreover, the highest appetite of the pigs in the HF105 group resulted in a higher daily intake of lysine/protein (despite the lower content of these nutrients in the HF diet) by these animals. The computed lysine/protein intake of the pigs from this group was close to CVB guidelines (1995), whereas the intake of this nutrient by pigs of the control group exceeded this recommendation, probably resulting in worse utilization and deposition, except for the pigs in group HF80, which showed compensatory growth during this period.

During the time when compensatory protein deposition was observed, pigs deposited similar amounts of fat compared with those continuously fed a low fibre diet, and even more than pigs fed the high-fibre diet throughout the experiment. During the later period of the realimentation, fat deposition predominated, similarly as in animals previously restricted with feed intake (Skiba et al., 2002). This confirms that pigs showing compensatory growth have a great pressure for protein deposition, even at the expense of fat deposition, similarly to what has been 
observed in very young pigs (Close et al., 1978). Moreover, this also confirms that the compensatory response is directed at those body components whose growth was the most reduced during the restriction, as was also suggested by other authors (de Greef, 1992). In the case of our pigs, the compensatory response included protein and fat, in contrast to pigs with previously restricted protein intake, which deposit more protein but a similar amount of fat compared with animals consistently fed adequately (Kyriazakis et al., 1991; de Greef, 1992). Earlier works (Kyriazakis and Emmans, 1992; Bikker, 1994; Skiba et al., 2002) had shown that pigs forced into compensatory growth by previous feed/energy restriction also deposited more fat in the body, as accretion of this body component was the most reduced during restriction. Greater fat deposition ensuing after compensatory protein deposition resolved, resulted, however, in better energy utilization. In contrast, when the animals showed compensatory growth, energy utilization for growth did not differ from conventionally growing pigs, whereas protein utilization was significantly enhanced, indicating that improvement of protein utilization for growth could contribute to the compensatory response.

Finally, the protein content in the body of the two previously restricted groups of pigs did not differ significantly from pigs fed adequately throughout the experiment or from the pigs continuously fed a high-fibre diet. The same trend was observed for adiposity, water and ash content, except for the pigs continuously fed a high-fibre diet, which had considerably less fat than the animals in the control group. Thus, both groups of previously restricted pigs compensated their chemical body composition. Nevertheless, when overall performance was considered, only pigs restricted up to a lower body weight grew at a similar rate, deposited the same amount of protein, and took the same number of days to reach the final weight as the non-restricted pigs. Thus, only these animals showed complete compensation, whereas those subjected to longer restriction (feeding on the high-fibre diet up to $80 \mathrm{~kg} \mathrm{BW}$ ) showed what is called partial compensation (Hogg, 1991).

In studies on the growth of animals, their adiposity can be expressed as the fat:protein ratio in their empty body. Thus, it seems purposeful to compare how this parameter varied during growth of the particular groups of pigs by using an allometric equation $\left(\mathrm{Y}=a \times \mathrm{X}^{b}\right)$. In this equation, $b$ is the slope of the regression curve, it is also termed the growth coefficient. The intercept $a$ has no biological meaning, however, it is the value of $\mathrm{Y}$ when $\mathrm{X}$ equals one. Positive allometry occurs when $b>1, \mathrm{Y}$ is then faster growing than $\mathrm{X}$. In negative allometry $(b<1)$, the relative increase of $\mathrm{Y}$ is smaller than $\mathrm{X}$. If $b=1$ the components $\mathrm{Y}$ and $\mathrm{X}$ grow at the same rate (isometrically). The values of coefficient $b$ found in our experiment indicate that the rate at which adiposity increased was below 1 in all groups of pigs. This means that negative allometry was observed, and that adiposity increased more slowly than the body weight of the pigs. Similar results 
were reported by Quiniou and Noblet (1995), who showed that the coefficient of the growth rate of adipose tissue of pigs growing from 15 to $110 \mathrm{~kg} \mathrm{BW}$ was below 1, regardless of the pigs' obesity. The differences in the values of coefficient $b$ between our groups of animals undoubtedly resulted from changes in the amount of protein and fat deposited by the animals of particular groups during restriction and realimentation. Because fat accretion showed the greatest diversity, it seems that this had the greatest impact on the value of coefficient $b$. The growth rate of protein and fat is genetically conditioned, but the results of our experiment indicate a potential for manipulation of the proportion between these body components within the same genotype via a "nutritional" way of exploiting the compensatory growth phenomenon. It seems to offer the potential of improving culinary quality (especially tenderness) of pork as well as its taste. Enhanced protein deposition is usually associated with an increased rate of protein turnover exhibited by compensating animals (Rossi et al., 2001), which positively influences meat tenderness (Therkildsen et al., 2002). Some authors reported, however, that meat tenderness could be influenced by the duration of realimentation (Kristensen and Emmans, 2002). Moreover, literature data indicate that an enhanced amount of fat deposited daily can also increase to some extent the intramuscular fat content in meat. This was evidenced in a study carried out with steers (Schoonmaker et al., 2004), as after removal of a growth suppressor (restricted feed/energy intake) the animals grew faster and, at target weight, were fatter, had a higher intramuscular fat content in the musculus longissimus dorsi compared with animals fed adequately throughout. Consequently, meat marbling of these animals also increased. Based on our results it seems that incorporating compensatory growth into the growth pathway of pigs in a manner resembling outdoor production (consuming an increased amount of fibre for a specified period) could offer the possibility of improving pork tenderness, but the precise explanation of this issue needs more detailed study.

\section{CONCLUSIONS}

Our results confirm that the compensatory response is temporary and occurs with the greatest intensity in the first few weeks after changing a restriction to realimentation and is more intensive in younger (restricted up to $50 \mathrm{~kg} \mathrm{BW}$ ) than in older (restricted up to $80 \mathrm{~kg} \mathrm{BW}$ ) pigs. The faster growth rate exhibited during the compensatory response is closely connected with greater protein deposition. Moreover, better protein utilization for growth could contribute to the compensatory response, and energy utilization seems to be of less importance. These results showed that incorporating compensatory growth into the outdoor 
production system could have a positive effect (however, only temporary) on protein deposition. Although, taking into account overall protein deposition, compensating pigs were similar to those fed under conditions similar to outdoor and to those fed conventionally as well. Our results also indicate that it is possible to regulate the growth rate and accretion of protein and fat in the body (via the phenomenon of compensatory growth). Furthermore, the culinary quality of the meat of such growing animals can be favourably influenced.

\section{REFERENCES}

AOAC, 1994. Association of Official Analytical Chemists, Officials Methods of Analysis. $15^{\text {th }}$ Edition. Washington, DC

Bikker P., 1994. Protein and lipid accretion of body components of growing pigs: effects of body weight and nutrient intake. PhD. Thesis, Wageningen University (The Netherlands), pp. 1-203

Close W.H., Mount L.E., Brown D., 1978. The effects of plane of nutrition and environment temperature on the energy metabolism of the growing pigs. 2. Growth rate including protein and fat deposition. Brit. J. Nutr. 40, 423-430

CVB, 1995. Tables of Feedstuffs. Information about Composition, Digestibility and Feeding Value (in Dutch), No. 18. Central Veevoeder Bureau, Lelystad (The Netherlands)

De Greef K.H., 1992. Prediction and production: Nutrition induced tissue partitioning in growing pigs. PhD. Thesis, Wageningen University (The Netherlands), pp. 1-117

Hogg B.W., 1991. Growth Regulation of Farm Animals. In: A.M. Pearson, T.R. Duston (Editors). Advan. Meat Res. 7, 103-134

Huxley J.S., 1932. Problems of Relative Growth. Methnen, London

Kotarbińska M., 1971. The chemical composition of the body in growing pigs. Rocz. Nauk. rol. B-93, 129-135

Kristensen L., Therkildsen M., Riis B., Sørensen M.T., Oksbjerg N., Purslow P.P., Ertbjerg P., 2002. Dietary-induced changes of muscles growth rate in pigs: Effects on in vivo and postmortem muscle proteolysis and meat quality. J. Anim. Sci. 80, 2862-2871

Kyriazakis I., Emmans G.C., 1992. The effects of varying protein and energy intake on the growth and body composition. 2 . The effects of varying both energy and protein intake. Brit. J. Nutr. 68, 615-624

Kyriazakis L., Stamataris C., Emmans G.C., Whittemore C.T., 1991. The effects of food protein content on the performance of pigs previously given foods with low or moderate protein content. Anim. Prod. 52, 165-174

Lawrence T.L.J., Fowler V.R., 2002. Growth of Farm Animals. $2^{\text {nd }}$ Edition. CABI Publishing, pp. 229-254

Quiniou N., Noblet J., 1995. Prediction of insular body composition from protein and lipid deposition in growing pigs. J. Anim. Sci. 73, 1567-1575

Rossi E., Loerch S.C., Keller H.L., Willett L.B., 2001. Effects of dietary crude protein concentration during periods of feed restriction on performance, carcass characteristics, and skeletal muscle protein turnover in feedlot steers. J. Anim. Sci. 79, 3148-3157

Schoonmaker J.P., Fluharty F.L., Loerch S.C., 2004. Effect of source and amount of energy and rate of growth in the growing phase on adipocyte cellurality and lipogenic activity in the intramuscular and subcutaneous fat depots of Holstein steers. J. Anim. Sci. 82, 137-148 
Skiba G., 2005. Physiological aspects of compensatory growth in pigs. J. Anim. Feed Sci. 14, Suppl. $1,191-203$

Skiba G., Fandrejewski H., Raj S., Weremko D., 2001. The performance and body composition of growing pigs during protein or energy deficiency and subsequent realimentation. J. Anim. Feed Sci. 10, 633-647

Skiba G., Fandrejewski H., Raj S., Weremko D., 2002. The influence of previous protein or energy restriction of young pigs on their daily gain composition. J. Anim. Feed Sci. 11, 299-308

Skiba G., Raj S., Weremko D., Fandrejewski H., 2006. Compensatory response of pigs previously fed a diet with increased fibre content. 1. Growth rate and voluntary feed intake. J. Anim. Feed Sci. 15, 393-402

Therkildsen M., Riis B., Karlsson A., Kristensen L., Ertbjerg P., Purslow P.P., Dall Aasyng M., Oksbjerg N., 2002. Compensatory growth response in pigs, muscle protein turn-over and meat texture: effects of restriction/realimentation period. Anim. Sci. 75, 367-377 